Journal of Animal and Veterinary Advances 18 (1): 18-23, 2019

ISSN: $1680-5593$

(C) Medwell Journals, 2019

\title{
Evaluation of the Daily Bush Meat Intake in Urban Household Consumption in Brazzaville, the Capital City of the Republic of Congo
}

\author{
${ }^{1}$ R.A. Mbete, ${ }^{1} \mathrm{H}$. Banga-Mboko, ${ }^{2} \mathrm{P}$. Racey, ${ }^{3} \mathrm{C}$. Vermeulen, \\ ${ }^{3}$ Jean-Louis Doucet, ${ }^{4}$ P.L. Leroy and ${ }^{4}$ J.L. Hornick \\ ${ }^{1}$ Universite Marien Ngouabi, Ecole Nationale Superieure d'Agronomie et de Foresterie, \\ BP 69, Brazzaville, Republique du Congo \\ ${ }^{2}$ Centre for Ecology and Conservation, University of Exeter, Cornwall, UK \\ ${ }^{3}$ Gembloux Agro-Bio-Tech, Laboratoire de Foresterie Des Regions Tropicales et Subtropicales, \\ Unite De Gestion Des Ressources Forestieres et Des Milieux Naturels, \\ Passage Des Deportes, 2, Universite de Liege, B-5030 Gembloux, Belgique \\ ${ }^{4}$ Institut Veterinaire Tropical, Faculte De Medecine Veterinaire, Universite De Liege, \\ 20 Bd Colonster, B43 Sart Tilman 4000 Liege, Belgique
}

\begin{abstract}
Bushmeat is of major importance to the food security of urban and rural populations of the Congo Basin. A quantitative survey of bush meat consumption was undertaken in Brazzaville, involving about 1,050 urban households. The survey's objectives were to evaluate the bush meat intake. The meat was drawn essentially from three mammalian orders-artiodactyls $(50.2 \%)$, rodents $(28.1 \%)$ and primates $(13.3 \%)$. The average daily bushmeat consumption per capita was estimated at $14.03 \pm 33.8 \mathrm{~g}$ or $5.2 \mathrm{~kg}$ per inhabitant per year and the total annual consumption in Brazzaville at 5121 tons. The probability distribution of mean daily bushmeat intake by individual was highly asymmetric and assumed to be poisson type with a $\lambda$ value close to $7 \mathrm{~g} /$ day. This survey highlights the importance of implementing a new forest policy involving local and native populations in the sustainable management of protected areas and hunting zones.
\end{abstract}

Key words: Brazzaville, consumption, fauna, food, household, wild meat

\section{INTRODUCTION}

Bush meat is defined as any non-domesticated terrestrial mammals, birds, reptiles and amphibians harvested for food consumption (Nasi et al., 2008). Its trade per year ranges from 1-5 mil.ton which is equivalent to twice the annual production of beef in France (Fa et al, 2003).

Fargeot and Dieval (2000) estimate annual consumption in Bangui, Central African Republic to be of the order of 9,500 tons per year of which at least half passes through formal markets growing urban populations have been cited as the primary driver of high levels of bush meat trade in Central Africa (Van Vliet and Mbazza 2011). Market studies (Nasi et al., 2008; Mbete et al., 2011b) show that residents of the Congo Basin countries eat as much if not more, meat as many residents of northern industrial countries (average of $47 \mathrm{~kg} /$ person/year versus $30 \mathrm{~kg} /$ person/ year) and that urban families eat less bushmeat than rural families.
The Congo has a diverse and abundant animal fauna which provides a major source of animal protein in the diet of local people and contributes to household economies (Mbete et al., 2011a).

Like most of sub-Saharan large cities in Africa, Brazzaville has experienced an accelerated demographic growth in recent decades with an annual rate of increase of . 4.8\% (Trefon and De Maret, 1999). Such urbanization increases the demand for animal protein and concentrates it in a way which local breeding and fishing cannot entirely satisfy.

In Brazzaville many markets are largely supplied with bushmeat, stemming from the Mayombe forest, the Chaillu massif and the large northern forest (Mbete et al., 2011b). The amount of meat available in urban markets is generally considered to be stable (Albrechtsen et al., 2005; East et al., 2005) with a great diversity. Blue duikers (Cephalophus monticola), cane rats (Tryonomys swinderianus), brush-tailed porcupines (Atherurus africanus), red river hogs (Potamochoerus porcus) and diverse monkeys such as Cercopithecus, Cercocebus and

Corresponding Author: H. Banga-Mboko, Universite Marien Ngouabi, 
Colobus spp. are the most represented species in the markets of the capital-city (Fa et al., 2005). Nowadays, Brazzaville alone concentrates one third of the overall population of Congo in an environment where bushmeat and Non-Timber Forest Products (NTFP) still play an essential role in the diet (Poulsen et al., 2009).

The assumption that urban consumption is the primary driver of high levels of bush meat trade in Central Africa is based on the large quantities of bush meat passing through urban markets rather than on measured consumption data (Jones-Bowen and Pendry, 1999).

A similar survey undertaken by Delvingt et al. (2001) in villages around the $\mathrm{Dj}$ a reserve in Cameroon, the Odzala National Park in the Congo and Ngotto forest in the Central African Republic, revealed that the average bush meat consumption in rural communities varies between 80-160 g/person/day.

Mbete et al. (2010) and later Mbete et al. (2011b) drawn up the socio-economic profile of bush meat consumers, however, the quantities and frequencies of bush meat intakes in Brazzaville were not investigated.

We hypothesized that in case of Congo bush meat intake may be greater in Brazzaville than in rural communities. Therefore, the objective of the study was to quantify daily bush meat intake per inhabitant in Brazzaville city.

Investigation on bushmaeat intake may be helpful for the government and also constitutes one of the fundamental elements to be taken into account in developing a strategy for managing the demand of wild meat in Congo.

\section{MATERIALS AND METHODS}

Study area: The study was undertaken in Brazzaville located in the Southern part of the Congo. The annual rainfall ranges between 1,400-1,600 mm (Samba-Kimbata, 2002). Brazzaville is surrounded by grasslands and woodlands, moist forests being in Northern and coastal parts of the country.

Methodology: The survey was conducted from May 1st-October 31st during the open hunting period. A sample of 1.050 households had been selected and the survey was carried out as previously described by Mbete et al. (2011a). The questionnaire was structured into two parts, meat consumed by the family during a meal containing meat and the monthly frequency of bushmeat intake. The mean level of bush meat consumed per day and per individual was estimated according to the following formula:
Daily individual bushmeat in take $(\mathrm{g} / \mathrm{day})=\frac{\mathrm{MC} \times \mathrm{MF}}{30 \times \mathrm{FS}}$

Where:

$\mathrm{MC}=$ Mean quantity of meat consumed by the family during a meal containing meat $(\mathrm{g})$

$\mathrm{MF}=$ Mean Monthly Frequency of bushmeat intake $\left(\mathrm{mo}^{-1}\right)$

FS = Family Size, estimated at $5.7 \pm 3.2$ persons (Mbete et al., 2011b)

Statistical analysis and calculations: The Software Epi Info Version 6.0 was used for computerizing data collected during the survey. Afterwards, data were transferred into Software SPSS (SPSS., 1999) for statistical analysis. Data collected from quantitative surveys were subjected to a descriptive statistical analysis, including a bi-variate analysis using contingency tables. The Chi-square test was used to determine the association between two variables from the contingency tables. This association was considered to be significant if $\mathrm{p} \leq 0.05$.

The continuous values were expressed as means \pm standard deviation within each of the families interviewed.

\section{RESULTS AND DISCUSSION}

Meat consumed by the family during a meal containing meat: The distributions of occurrence and frequency of consumption of meat-based products in households are shown in Fig. 1. A total of 6845 meat-based meals were reported by households. The most frequently consumed meal was imported frozen beef, (14.7\%). Bushmeat made up $11 \%$ of meals behind beef, fish accounted for $12.9 \%$ and chicken and pork $12.7 \%$ each. Different sensibilities also emerged with respect to the food preference of adults and children with adults showing a greater preference for bushmeat $(13.5 \%)$ and children less $(6.8 \%)$.

Frequency of bushmeat consumption: The frequency with which households purchased bushmeat is shown in Table 1. About $60 \%$ of households bought bushmeat at least once a month. The results showed a relationship between the socio demographic characteristics of the interviewed head of household and the frequency of bushmeat purchase $\left(\chi^{2}=297 ; \mathrm{p}<0.001\right)$.

The analysis of the results concerning the last meal including bushmeat before the survey revealed that $46.1 \%$ households had consumed bushmeat once in the preceding month (Table 2). There was a relationship 


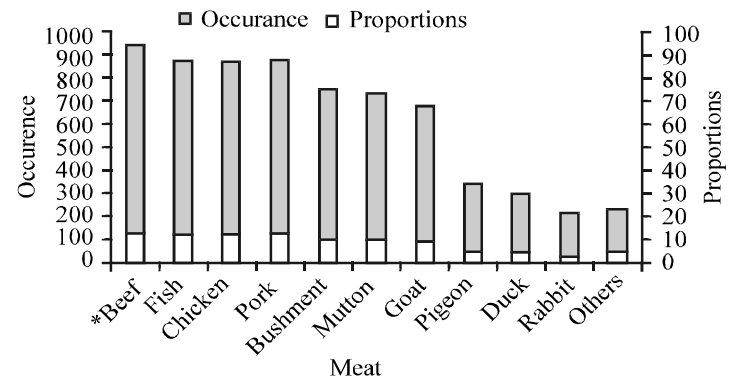

Fig. 1: Frequencies distribution of meal associated to different types of meat in the dietary regime of the surveyed households: (*Imported frozen)

Table 1 : Bushmeat purchase frequency by surveyed Brazzaville households Purchase frequencies $\quad$ Percentage responses $(\%)(n=793)$ Less than once a month 40.5 $\begin{array}{ll}\text { Once a month } & 25.8 \\ \text { Twice am } & 15.5\end{array}$

Twice a month $\quad 15.5$

Four times a month $\quad 13.5$

$\begin{array}{ll}\text { More or equal to } 5 \text { times a month } & 4.7\end{array}$

Table 2: Time interval between bushmeat consumption by surveyed Brazzaville households

\begin{tabular}{lc}
\hline Consumption interval (days) & Answers (\%) $(\mathrm{n}=878)$ \\
\hline 30 & 46.1 \\
$31-90$ & 17.1 \\
$91-180$ & 10.6 \\
$181-365$ & 15.1 \\
$\geq 365$ & 11.1 \\
\hline
\end{tabular}

between the frequency of bushmeat consumption and the socio demographic characteristics of the surveyed head of household $\left(\chi^{2}=387 ; \mathrm{p}<0.001\right)$.

A preference order of the most prized animal species in Brazzaville was established (Fig. 2) and mammals were clearly the first choice for consumers. Artiodactyls (blue duiker and red river hog) were the most preferred $(50.2 \%)$ followed by rodents such as the African brush-tailed porcupine $(28.1 \%)$ and primates $(13.3 \%)$. Reptiles (3.8\%), proboscidians $(2.2 \%)$, carnivores $(1.5 \%)$ and birds $(0.9 \%)$ were the least preferred.

Evaluation of quantities of meat intake: The average amount of bushmeat consumed per meal is shown in Fig. 3. The majority of meals contained up to a kilogram. Knowing the family sizes and the declared frequency of meat intake, the mean individual intake of bushmeat was evaluated at $14.03 \mathrm{~g} /$ day $( \pm 33.8)$. However, the probability distribution of intake was largely asymmetric and estimated to be of Poisson type with a $\gamma$ value of $7 \mathrm{~g} /$ day. (Fig. 4).

The probability distribution of daily decagrams of bushmeat intake by individuals in Brazzaville is shown in (Fig. 4). Finally with a population of $1,029,980$ inhabitants, the total household consumption of bushmeat in Brazzaville was estimated at $14 \mathrm{~g}$ t/day or $5.2 \mathrm{~kg}$ per inhabitant per year this is equivalent to 5,121 tons per year.

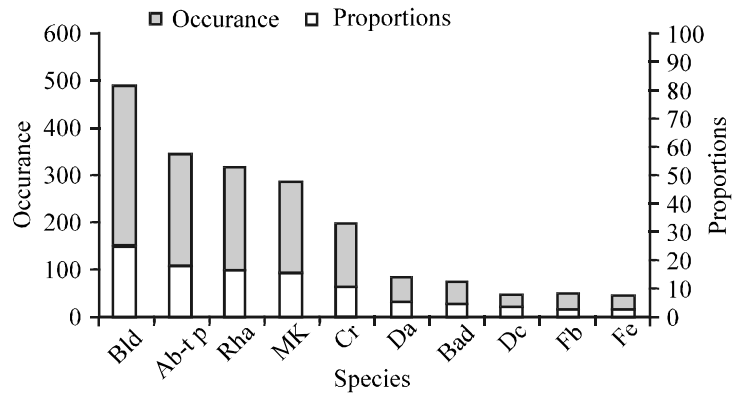

Fig. 2: Species preferences of surveyed households during the period of bushmeat abundance on Brazzaville markets. Bld: Blue Duiker; Ab-t p: African Brush-Tailed porcupine; Rrh: Red River Hog; MK: Monkey; Cr: Cane Rat; Da: Dwarf Antelope; Bad: Bay Duiker; Dc: Dwarf Crocodile; Fb: Forest Buffalo; Fe: Forest Elephant

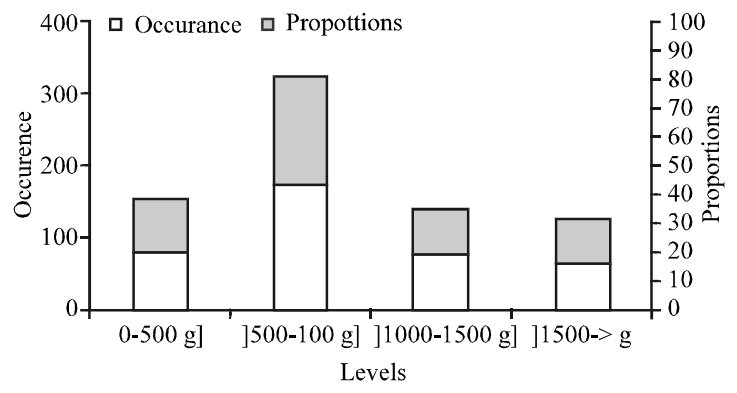

Fig. 3: Bushmeat intake per household in a bushmeat containing meal

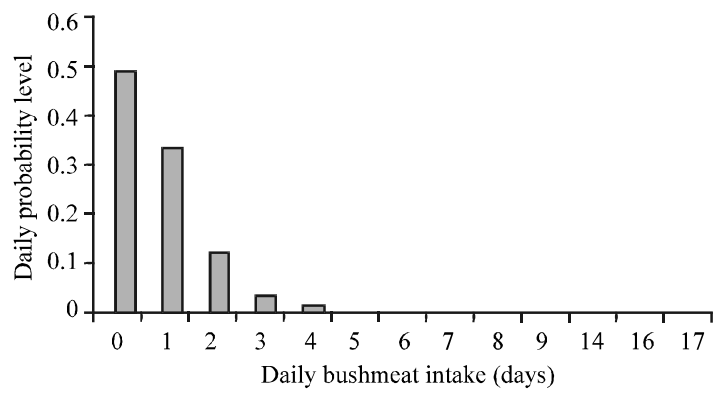

Fig. 4: Probability distribution of mean daily decagrams (dag) bushmeat intake by surveyed individuals in Brazzaville

Limits of the methods: Household bushmeat consumption has been studied in most Central African countries, generally through surveys. As was emphasized by Chardonnet et al. (1995), the sampling methods used in most studies do not justify the relevance of the results and it is often difficult to apply such results to the whole target population. In most cases, the studies do not last long enough and do not follow up on the households involved in bushmeat consumption in order to integrate 
variation in consumption over time. Therefore, in order to compensate for biases inherent in survey protocols, the frequencies and quantities of bushmeat consumed in Brazzaville households could easily be obtained by undertaking repetitive surveys.

Meat consumed by the family during a meal containing meat: The frequency of bush meat found in the present study was higher compared to Kinshasa (Wilkie and Carpenter, 1999; De Merode et al., 2004). One of the reasons might be the price. In fact in Kinshasa, bushmeat costs twice or three times more than beef on the market (Bahuchet, 2000). As also shown by Wilkie et al. (2005), Fa et al. (2009) and Mbete et al. (2011b) in large urban cities in Central Africa where economy is more cash-based, the erosion of the purchasing power in households constitutes a limiting factor in satisfying the consumer's increasing demand for bushmeat. This tendency is also confirmed by the relatively low frequency of bushmeat purchase. Such a disparate purchasing pattern probably arises from income level and also from the household's ability to preserve what they purchase (Wilkie et al., 2005). From that point of view it appears therefore that bushmeat becomes in an area where there is much poverty, a luxury food. Because of this as already noted by Albrechtsen et al. (2005) and others it is less frequently consumed in most urban households than other meats.

Meat consumed by the family during a meal containing meat: In the analysis of the composition of meals, the frequency of appearance of certain foods is informative. Although, domestic meat (beef, fish, chicken, pork, mutton) appeared in $64.6 \%$ meals, bushmeat was present in only $9.2 \%$ cases. The prevalence of domestic meat for which bushmeat constitutes in some respects an alternative is explained by the fact that they are cheaper and therefore, more accessible to consumers. Linkages between household wealth, bushmeat and other animal protein consumption are not invariant evidence from Rio Muni (Equatorial Guinea) shows that a high purchasing power dictates diet choice (Albrechtsen et al., 2005; Fa et al., 2009). For households with average or low incomes, the results show that fish constituted the alternative solution to the increasing prices of bushmeat which corroborates the observations of (Binot and Cornelis, 2004) in Libreville. These researchers indicated that fish and bushmeat were interchangeable dietary substitutes.

Consumed meats: Our study showed a wide range of species being sold and consumed as bushmeat. However, some species are more sought after than others due to their symbolic and cultural value. This conclusion is supported by Mbete et al. (2011b) in their study on household bushmeat consumption in Brazzaville, the Congo. In their view, Brazzaville consumers preferred artiodactyls (50.2\%) and rodents (28.1\%). Primates, mostly the small ones, represent $13.3 \%$ of those referred to by the consumers as their first choice. This is also observed in large Central African cities and also confirms the conclusions of Kumpel et al. (2010) and Mbete et al. (2011a) that in the Congo Basin, duikers, the suids, rodents and primates appear among the most prized animals on the bushmeat market.

Daily intake: From a quantitative point of view, Brazzaville populations consume an average quantity of bushmeat equivalent to more than $5 \mathrm{~kg} /$ person/year and the daily average consumption was $14 \pm 34 \mathrm{~g} /$ person/day, the large variance indicating a strong asymmetric distribution of probability. Indeed, more than $95 \%$ of the populations show an intake lower than $30 \mathrm{~g} /$ day.

The result support a survey undertaken by Delvingt et al. (2001) in villages around the Dja reserve in Cameroon, the Odzala National Park in the Congo and Ngotto forest in the Central African Republic, revealed that the average bushmeat consumption varies between 80 and $160 \mathrm{~g} /$ person/day that is about 10 times the estimated quantity consumed by residents of Brazzaville. As a comparison, the average intake of chicken meat was estimated at $21 \mathrm{~g} /$ person/day (FAO., 2008). Further surveys carried out in Rio Muni in Equatorial Guinea revealed that the average bush meat consumption was estimated at $32 \mathrm{~g} /$ person/day (Thibault and Blaney, 2003; Puits, 2003; Fa et al., 2009)

The results of the present study are in agreement of Wilkie and Carpenter (1999) who reported that rural consumption outweighs urban consumption in every country in Central Africa, often by a large margin. The assumption that urban consumption is the primary driver of high levels of bushmeat trade in Central Africa is based on the large quantities of bushmeat passing through urban markets rather than on measured consumption data (Jones-Bowen and Pendry, 1999). Since, much bush meat may pass through informal channels such as from rural hunters directly to urban consumers rather than through markets, established bushmeat markets channel only an unknown portion of total urban consumption (Bahuchet and Ioveva, 2000; Trefon and De Maret, 1999). Such findings have led to suggestions that the visible market trade in bushmeat may only be the tip of the iceberg and that the overall contribution of urban areas to bushmeat consumption may be far greater (Van Vliet and Mbazza, 2011). 
On the other hand, Chardonnet et al. (1995) suggest that while per capita urban consumption of bush meat is low, aggregate urban consumption is higher than aggregate rural consumption due to the high population density of urban areas. Our data contrast with the review of Van Vliet and Mbazza (2011) that shows that Libreville, the capital city, accounts for $40 \%$ of the population but accounts for $<14 \%$ of aggregate bush meat consumption. However, given current trends in population distribution, urban demand for bush meat may come to exceed rural demand. Finally, the results reject our hypothesis formulated at the beginning of the study but agree with the assertion that bush meat consumption in urban cities is lower than in rural city.

\section{CONCLUSION}

Bush meat remains an essential source of animal protein in the diet of the majority of Brazzaville households. However, in a poverty-stricken context, it remains a luxury item, less frequently consumed in most urban households, particularly for those with an average income. Overall, the urban population of Brazzaville appears to consume a moderate level of bush meat, however with negative impacts on the wildlife population.

\section{SUGGESTIONS}

This study suggests the importance of implementing multiple solutions to combat the threats to some species, especially, mammals. Such tools involve legislation, training, communication and breeding wild species.

\section{ACKNOWLEDGEMENT}

The first researcher was granted both by Marien Ngouabi scholarships and the financial support from The Ministry of Scientific research in Congo.

\section{REFERENCES}

Albrechtsen, L., J.E. Fa, B. Barry and D.W. Macdonald, 2005. Contrasts in availability and consumption of animal protein in Bioko Island, West Africa: The role of bushmeat. Environ. Conserv., 32: 340-348.

Bahuchet, S. and C. Ioveva, 2000. [From the Forest to the Market: Game Trade in Southern Cameroon]. In: Man and the Tropical Forest, Bahuchet, S., D. Bley, H. Pagezy and N. Vernazza-Licht (Eds.). Editions de Bergier, France, Paris, ISBN: 9782951184039 , Pages: 533-558 (In French).
Bahuchet, S., 2000. [The Bush Meat Sector]. In: Todays Tropical Forest Peoples: Thematic Approach of the APFT Program, Bahuchet S. (Ed.). Tropenbos, Bruxelles, Belgium., ISBN: 9789051130485, pp: 331-363.

Binot, A. and D. Cornelis, 2004. [Bibliographic Synthesis of the Bushmeat Sector]. Scientific Publishers, India, ISBN:9788172334307, Pages: 264.

Chardonnet, P., H. Fritz, N. Zorzi and E. Feron, 1995. Current Importance of Traditional Hunting and Major Contrasts in Wild Meat Consumption in Sub-Saharan Africa. In: Integrating People and Wildlife for a Sustainable Future, Bissonette, J.A. and P.R. Krausman (Eds.). The Wildlife Society, Bethesda, Maryland, USA., ISBN:9780933564121, pp: 304-307 (In French).

De Merode, E., K. Homewood and G. Cowlishaw, 2004. The value of bushmeat and other wild foods to rural households living in extreme poverty in Democratic Republic of Congo. Biolog. Conserv., 118: 573-581.

Delvingt, W., M. Dethier, P. Auzel and P. Jeanmart, 2001. [Badoo Hunting: Sustainable Customary Management or Looting of Game Resources? In: The Forest of Men: Village Terroirs in African Rainforest Delvingt, W. (Eds.). Delvingt, W. (Eds.). Gembloux, Belgium, ISBN:9782870160640, pp: 65-92.

East, T., N.F. Kumpel, E.J. Milner-Gulland and J.M. Rowcliffe, 2005. Determinants of urban bushmeat consumption in Rio Muni, Equatorial Guinea. Biolog. Conserv., 126: 206-215.

FAO., 2008. [State of Play and Cartography of the Poultry Sector in Congo]. Food and Agriculture Organization, Rome, Italy. (In French).

Fa, J.E., D. Currie and J. Meeuwig, 2003. Bushmeat and food security in the Congo Basin: Linkages between wildlife and peoples future. Environ. Conserv., 30: 71-78.

Fa, J.E., L. Albrechtsen, P.J. Johnson and D.W. Macdonald, 2009. Linkages between household wealth, bushmeat and other animal protein consumption are not invariant: Evidence from Rio Muni, Equatorial Guinea. Anim. Conserv., 12: 599-610.

Fa, J.E., S.F. Ryan and D.J. Bell, 2005. Harvest rates of bushmeat species in afro tropical forests. Biolog. Conserv., 121: 167-176.

Fargeot, C. and S. Dieval, 2000. [The consumption of game to Bangui, some economic and biological data (In French)]. Canopee, 18: 5-7.

Jones-Bowen, E. and S. Pendry, 1999. The threat to primates and other mammals from the bushmeat trade in Africa and how this threat could be diminished. Oryx., 33: 233-246. 
Kumpel, N.F., E.J. Milner-Gulland, G. Cowlishaw and J.M. Rowcliffe, 2010. Incentives for hunting: The role of bushmeat in the household economy in rural Equatorial Guinea. Hum. Ecol., 38: 251-264.

Mbete, P., C. Ngokaka, F. Akouango, N. Bonazebi and J. Vouidibio, 2010. [Evaluation of the quantities of game taken around the Odzala-Kokoua National Park and their impact on the degradation of biodiversity]. J. Anim. Plant Sci., 8: 1061-1069.

Mbete, R.A., H. Banga-Mboko, C. Ngokaka, Q.F. Bouckacka III and I. Nganga et al., 2011b. [Profile of sellers of meat and valuation of biomass marketed in the municipal markets of Brazzaville Congo (In French)]. Trop. Conserv. Sci., 4: 203-217.

Mbete, R.A., H. Banga-Mboko, P. Racey, A. Mfoukou-Ntsakala and I. Nganga et al., 2011a. Household bushmeat consumption in Brazzaville, the Republic of the Congo. Trop. Conserv. Sci., 4: 187-202.

Nasi, R., D. Brown, D. Wilkie, E. Bennett and C. Tutin Van Tol et al., 2008. Conservation and use of Wildlife-Based Resources: The Bushmeat Crisis. University of Minnesota, Minneapolis, USA., Nasi, ISBN:9789292250836, Pages: 50.

Poulsen, J.R., C.J. Clark, G. Mavah and P.W. Elkan, 2009. Bushmeat supply and consumption in a tropical logging concession in Northern Congo. Conserv. Biolog., 23: 1597-1608.

Puit, M., 2003. [Study of the Commercialization of Bushmeat in the Rio Muni Continental Region, Equatorial Guinea]. University of Liege, Liege, Belgium,.
SPSS., 1999. SPSS Base 10.0 for Windows User's Guide. SPSS Inc, Chicago, Illinois, USA., ISBN: 9780130267290 , Pages: 537.

Samba-Kimbata, J.M., 2002. [Bioclimatic rhythm and phenological behavior of vegetation in the Republic of Congo (In French)]. Ann. Univ. Marien Ngouabi, 3: 81-92.

Thibault, M. and S. Blaney, 2003. The oil industry as an underlying factor in the bushmeat crisis in Central Africa. Conserv. Biolog., 17: 1807-1813.

Trefon, T. and P. de Maret, 1999. [Snack Nature in the Cities of Central Africa]. In: Man and the Rainforest Paris, Bahuchet, S., D. Bley, H. Pagezy and N. Vernazza-Licht (Eds.). Editions du Bergier, Chateauneuf, France, ISBN:9782951184039, pp: 559-573 (In French).

Van Vliet, N. and P. Mbazza, 2011. Recognizing the multiple reasons for bushmeat consumption in urban areas: A necessary step toward the sustainable use of wildlife for food in Central Africa. Hum. Dimensions Wildl., 16: 45-54.

Wilkie, D.S. and J.F. Carpenter, 1999. Bushmeat hunting in the Congo Basin: An assessment of impacts and options for mitigation. Biodiver. Conserv., 8: 927-955.

Wilkie, D.S., M. Starkey, K. Abernethy, E.N. Effa and P. Telfer et al., 2005. Role of prices and wealth in consumer demand for bushmeat in Gabon, Central Africa. Conserv. Biolog., 19: 268-274. 